
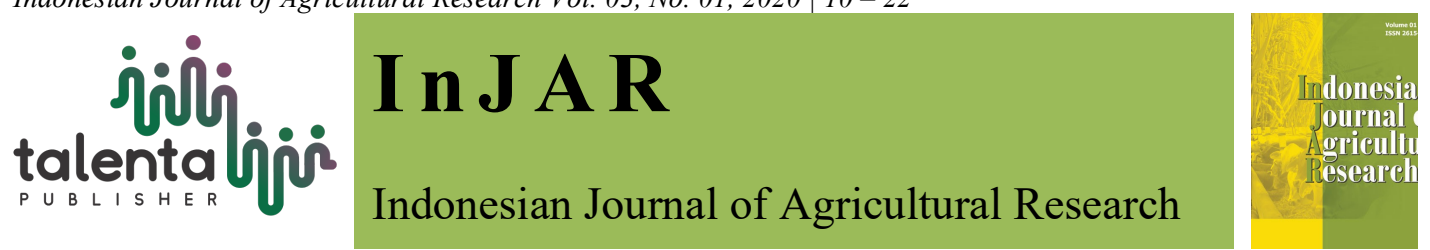

\title{
Effect of the Types and Percentages of Stabilizer on the Quality of Instant Garfish Condiment
}

\author{
Christine Marchelina, Hotnida Sinaga ${ }^{*}$ Linda Masniary Lubis \\ Department of Food Science and Technology, Faculty of Agriculture, Universitas Sumatera Utara, \\ Indonesia
}

\begin{abstract}
The purpose of this research was to determine the effect of stabilizer types and percentages on the quality of instant garfish condiment. The research used a group randomized design factorial with two factors, i.e.: types of stabilizer (CMC; arabic gum; gelatin) and percentage of stabilizer $(0.0 \% ; 0.5 \% ; 1 \% ; 1.5 \%)$. The results showed that stabilizer types had a highly significant effect on water absorption index, water solubility index, vitamin $\mathrm{C}$, and color index. Moreover, the stabilizer had no significant effect on organoleptic aroma and taste. In the meantime, stabilizer percentages had a highly significant effect on water absorption index, water solubility index, vitamin C, color index, and organoleptic aroma. However, the stabilizer percentages gave no significant effect on organoleptic taste. Interaction between the two factors had a highly significant effect on water absorption index and vitamin $\mathrm{C}$ and had a significant effect on color index. Furthermore, the interaction had no significant effect on water solubility index, organoleptic aroma and taste. The best treatment product was resulted from the use of $1.5 \%$ $\mathrm{CMC}$ as stabilizer.
\end{abstract}

Keywords: arabic gum, CMC, garfish, gelatin, stabilizer

Received 25 January 2020 | Revised 13 February 2020 | Accepted 05 April 2020

\section{Introduction}

In Indonesia, spices are widely used for seasoning, especially in traditional cuisine. The spices are used to enhance taste which is more acceptable. Beside being used for seasoning, spices are also used for condiment. There are many types of condiment that have different flavor characteristics in each region. In general, the main ingredients used are same, like chili, shallot, garlic, candlenut, sugar, and salt. The difference is the addition of other ingredients that gives a unique taste, for example garfish condiment which is from Manado, North Sulawesi. The condiment use smoked garfish so it has smoked flavor [1].

In the era of globalization, consumption and lifestyles change due to increasingly dense activity. These reasons make people choose things that are instant and have become a habit. It also

\footnotetext{
*Corresponding author at: Department of Food Science and Technology, Universitas Sumatera Utara, J1. Prof A.

Sofyan, No. 3, Medan, 20155, Indonesia

E-mail address: hotnida.sinaga@uq.net.au
} 
changed people's need for food, including instant condiment in both wet and dry (powdered) form, so that people practically don't need to collect spices for cooking [2]. Previous studies has shown that wet cahero condiment (chili, ginger, garfish) has good physicochemical and organoleptic values. The best treatment from the study was obtained from a comparison of $90 \%$ red chili with $10 \%$ red chili with a viscosity of $766 \mathrm{cP}$ and vitamin C levels $9.6 \mathrm{mg} / 100 \mathrm{~g}$ [3]. However, the condiment only has a shelf life of 1 week. Wet condiment was easily damaged due to high moisture content. Therefore it needs additional treatment, such as drying, to maintain quality and simplify serving of garfish condiment [4].

There are problems with instant condiment that stored for a long time such as clots. In addition, damaged due to fat oxidation and enzyme activity can affect organoleptic such as loss of taste, rancidity, and shorter shelf life. These damage can be minimized by adding stabilizers so that the quality of the product is more maintained [5]. In this research, instant garfish condiment was made by using several types and percentages of stabilizers and drying process. Stabilizers used were $\mathrm{CMC}$, arabic gum, and gelatin. $\mathrm{CMC}$ has function for flavor enhancer, water binder, and thickener [6]. Arabic gum functions as stabilizer and improves product texture [7]. Gelatin has functions as stabilizer, foaming agent, binding agent, emulsifier, and thickener [8]. The purpose of this research was to determine the effect of stabilizer types and percentages on the quality of instant garfish condiment.

\section{Material and Methods}

The materials used in this research were smoked garfish, chili, shallot, garlic, candlenut, CMC, arabic gum, gelatin, salt, sugar, cooking oil, and water. Reagensia used in this research were aquadest, ethanol pro analysis, ethanol 70\%, ascorbic acid, oxalic acid 3\%, sodium bicarbonate, 2,6-Dichlorophenol-indophenol Na, and 2,2-Diphenyl-1-picrylhydrazil.

\subsection{Producing Garfish Condiment}

Garfish condiment was made with a total weight of $250 \mathrm{~g}$ condiment. First, peeled and weighed the ingredients, such as red chili $20 \%$, cayenne pepper $15 \%$, shallot $10 \%$, and garlic $10 \%$. Both ingredients were boiled for 5 minutes and then drained. Then, smoked garfish $15 \%$ and candlenut $10 \%$ were roasted for 2 minutes. After that, mixed all ingredients and added salt $6 \%$, sugar $4 \%$, cooking oil $2 \%$, and stabilizer (CMC, arabic gum, gelatin) with amount of $0 \%, 0,5 \%$, $1 \%$, and $1,5 \%$ with blender.

\subsection{Producing Instant Garfish Condiment}

The condiment was placed on a baking sheet that has been coated with polypropylene plastic with $1-3 \mathrm{~mm}$ of thickness, then dried with the oven at $60{ }^{\circ} \mathrm{C}$ for 8 hours. The dried condiment was blend and sieved using 40 mesh sieve, then put into LDPE (Low Density Polyethylene) plastic. 


\subsection{Data Analysis}

The research used a group randomized design factorial with two factors, i.e.: types of stabilizer (CMC; arabic gum; gelatin) and percentage of stabilizer $(0,0 \% ; 0,5 \% ; 1 \% ; 1,5 \%)$. Each treatment is made in 3 replications, with total of 36 samples. Data were analyzed by analysis of variance (ANOVA) and treatment that have significant or highly significant effect followed by LSR (Least Significant Range) test. The analysis includes water absorption index, water solubility index, vitamin C, color index, organoleptic aroma, and taste.

\subsubsection{Water Absorption Index and Water Solubility Index}

Water Absorption Index and Water Solubility Index analyzes were performed with $1 \mathrm{~g}$ of sample (a) put into a centrifuge tube (b), added $10 \mathrm{~mL}$ of aquadest, homogeneous with vortex, centrifuged at $2000 \mathrm{rpm}$ at room temperature for 15 minutes, separated supernatant and residue. Then the residue was weighed (c) and heated to a constant weight (d), so that the weight of the evaporated water was known, while the entire supernatant was weighed (e) and put in a cup (f) and heated to a constant weight $(\mathrm{g})[9]$.

$$
\begin{aligned}
& \text { Water Absorption Index }=\frac{c-d}{a-(d-b)} \\
& \text { Water Solubility Index }=\frac{g-f}{e}
\end{aligned}
$$

\subsubsection{Vitamin C}

Analysis of vitamin C levels was carried out by the method of oxidimetry I [10]. This method is carried out in several stages:

a. $\quad$ Making Reagent Solutions

- Oxalic acid 3\% was prepared by dissolving oxalic acid crystals in aquadest.

- Standard ascorbic acid was made by weighing exactly $100 \mathrm{mg}$ of L-ascorbic acid and dissolved with $\mathrm{HPO}_{3}$ up to $100 \mathrm{~mL}$. The solution was diluted so that $1 \mathrm{~mL}=0,1 \mathrm{mg}$ ascorbic acid. The solution was kept away from sunlight and used in the new circumstances.

- Dye solution was prepared by dissolving $50 \mathrm{mg}$ of $\mathrm{Na}$ salt of 2,6-diclorophenol indophenol in $150 \mathrm{~mL}$ of hot aquadest containing $42 \mathrm{mg}$ of sodium bicarbonate. Dye cooled and diluted to $200 \mathrm{ml}$ with aquadest and filtered.

\section{b. Standardize Dye Solutions}

The dye solution was put into a micro burette. A $5 \mathrm{~mL}$ ascorbic acid standard solution was pipetted into an Erlenmeyer and added with $5 \mathrm{~mL}$ of $3 \%$ oxalic acid. Then titrated with dye solution until the pink color lasts for 15 seconds. The dye factor was calculated by the following formula. 


$$
\text { Dye Factor }=\frac{0,5}{\text { Titer }}
$$

c. Sample Preparation

Pipette $10-20 \mathrm{~mL}$ of sample to a $100 \mathrm{~mL}$ volumetric flask and then diluted with $\mathrm{HPO}_{3}$ until the sign and then filtered.

d. Sample extract testing

$10 \mathrm{~mL}$ sample extract was titrated with a standard dye solution until the final point, which was pink, lasted for 15 seconds. The titer obtained is a preliminary titer. Furthermore, the titration was repeated with a new sample extract and then titrated slowly until it reaches the final point. Titer should not be more than $3-5 \mathrm{~mL}$. Vitamin $\mathrm{C}$ can be calculated by the following formula:

$$
\text { Vitamin C (mg/100 g) }=\frac{\text { Titer } \times \text { Faktor dye } \mathrm{x} \text { Volume ekstrak total } \mathrm{x} 100}{\text { Volume ekstrak } \mathrm{x} \text { Volume sampel }}
$$

\subsubsection{Color Index}

The color index was measured by a Minolta Chroma Meter (CR 200 type, Japan). The sample was placed and press the start button to got the $\mathrm{L}$, $\mathrm{a}$, and $\mathrm{b}$ values from the sample with a range of 0 (black) to \pm 100 (white). The notation "a" represents the chromatic color mixture of redgreen with the value "+ a" (positive) from 0 to +100 for red and the value "-a" (negative) from 0 to -80 for green. The notation "b" states the chromatic color mixture of blue-yellow with the value "+ b" (positive) from 0 to +70 for yellow and the value "-b" (negative) from 0 to -80 for blue. Whereas L stated color sharpness, the higher the sharpness of the color, the higher the value of L [11]. Furthermore, from the values of $a$ and $b$ can be calculated ${ }^{\circ}$ Hue with the formula:

${ }^{\circ}$ Hue $=\tan ^{-1} \frac{b}{a}$. If the results obtained:

$$
\begin{array}{ll}
18^{\circ}-54^{\circ} & : \text { the product was red (R) } \\
54^{\circ}-90^{\circ} & : \text { the product was yellow red (YR) } \\
90^{\circ}-126^{\circ} & : \text { the product was yellow (Y) } \\
126^{\circ}-162^{\circ} & : \text { the product was yellow green (YG) } \\
162^{\circ}-198^{\circ} & : \text { the product was green (G) } \\
198^{\circ}-234^{\circ} & : \text { the product was blue green (BG) } \\
234^{\circ}-270^{\circ} & : \text { the product was blue (B) } \\
270^{\circ}-306^{\circ} & : \text { the product was blue purple (BP) } \\
306^{\circ}-342^{\circ} & : \text { the product was purple (P) } \\
342^{\circ}-18^{\circ} & : \text { the product was red purple (RP) }
\end{array}
$$




\subsubsection{Organoleptic Aroma and Taste}

Organoleptic aroma and taste was carried out by hedonic quality testing using 70 panelists. The hedonic quality test assessment uses a line scale with the lowest value of 1 (very dislike) and the highest value of 5 (very like). Organoleptic instant garfish condiment was done by adding condiment to water using a ratio of 1: 2 (condiment: water). The wet condiment was served together with rice to the panelists for their organoleptic assessment [12].

\section{Results and Discussions}

\subsection{Water Absorption Index}

Based on analysis of variants, the types of stabilizer had a highly significant effect $(\mathrm{P}<0.01)$ on water absorption index of instant garfish condiment. $\mathrm{P}_{1}$ treatment had a highly significant effect from $\mathrm{P}_{2}$ and $\mathrm{P}_{3}$ treatment. $\mathrm{P}_{2}$ treatment had a highly significant effect from $\mathrm{P}_{3}$ treatment. CMC had the higher water binding ability among arabic gum, gelatin, carrageenan, and sodium alginate. This caused the addition of CMC had the higher water absorption index than other stabilizers [13]. Correlation of the types of stabilizer on water absorption index can be seen in Figure 1.

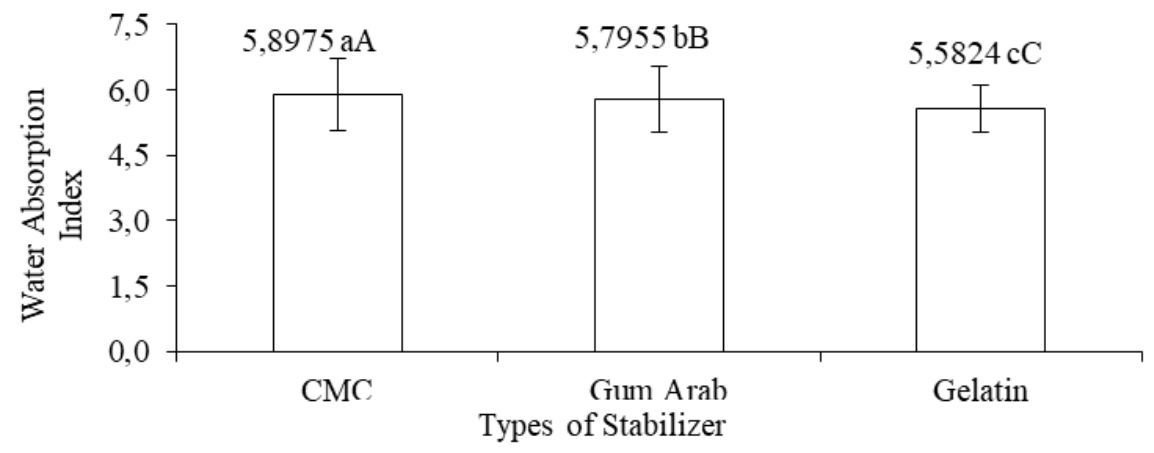

Figure 1. Correlation of the Types of Stabilizer on Water Absorption Index

Note: Different letter notations showed significant effect at $5 \%$ (lowercase) level and highly significant effect at $1 \%$ (uppercase) level

Based on analysis of variants, the percentages of stabilizer had a highly significant effect $(\mathrm{P}<0.01)$ on water absorption index of instant garfish condiment. $\mathrm{P}_{1}$ treatment had a highly significant effect from $\mathrm{P}_{2}, \mathrm{P}_{3}$, and $\mathrm{P}_{4}$ treatment. $\mathrm{P}_{2}$ treatment had a highly significant effect from $\mathrm{P}_{3}$ and $\mathrm{P}_{4}$ treatment. $\mathrm{P}_{3}$ treatment had a highly significant effect from $\mathrm{P}_{4}$ treatment. The higher percentage of stabilizer added, the more water was absorbed in the product so that the moisture content and water absorption index increased [14]. Correlation of the percentages of stabilizer on water absorption index can be seen in Figure 2. 


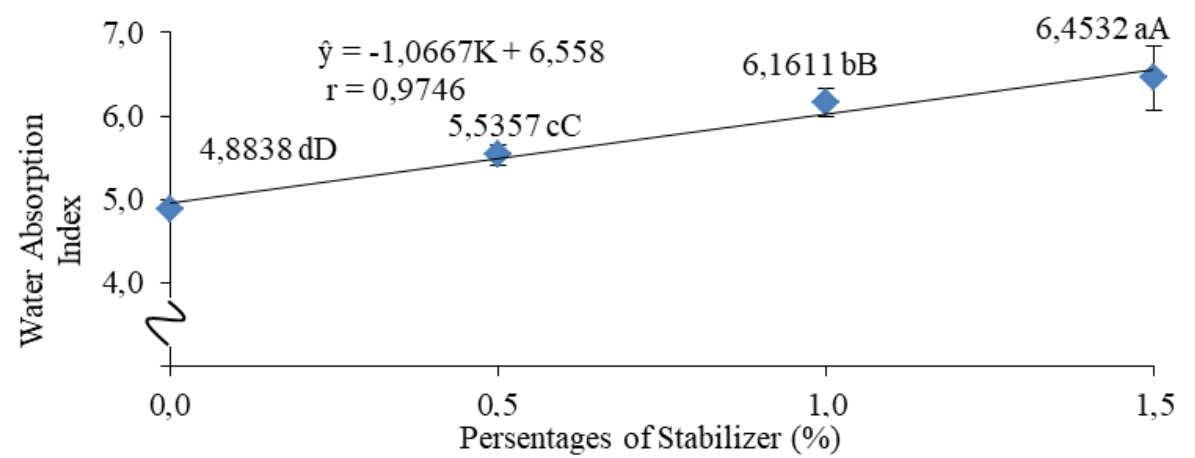

Figure 2. Correlation of the Percentages of Stabilizer on Water Absorption Index

Note: Different letter notations showed significant effect at 5\% (lowercase) level and highly significant effect at $1 \%$ (uppercase) level

Based on analysis of variants, interaction between the two factors had a highly significant effect $(\mathrm{P}<0.01)$ on water absorption index of instant garfish condiment. The combination of the types and percentages of stabilizer had a highly significant effect on water absorption index of instant garfish condiment. The addition of $1.5 \% \mathrm{CMC}$ had the higher water absorption index compared with other stabilizer. $\mathrm{CMC}$ had the ability to absorbed more water among other stabilizers that commonly used in product. The higher percentage of stabilizer will also increase water absorption index because more hydrocolloid particles bind to water [15]. Interaction between the two factors on water absorption index can be seen in Figure 3.

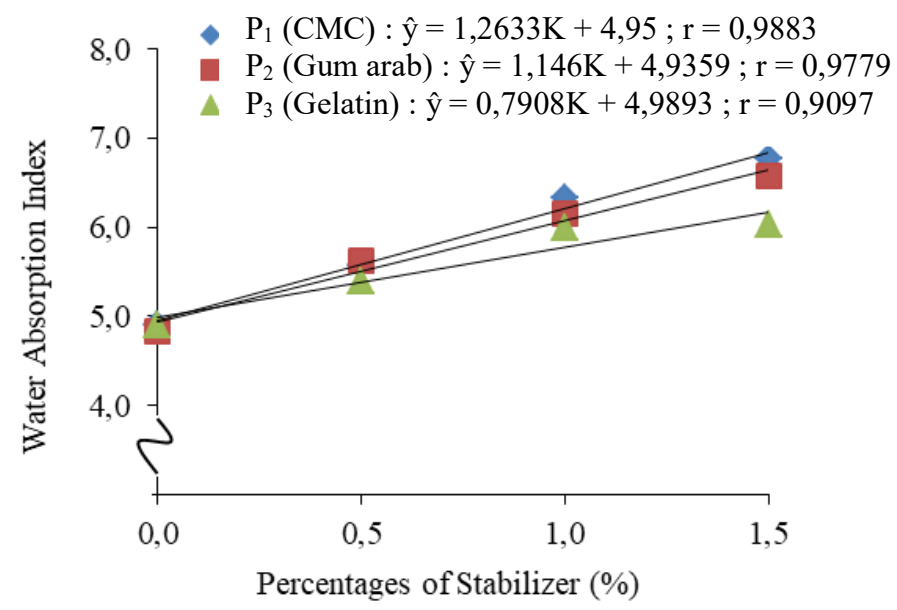

Figure 3. Interaction between the Types and Percentages of Stabilizer with Water Absorption Index of Instant Garfish Condiment

Note: Different letter notations showed significant effect at 5\% (lowercase) level and highly significant effect at $1 \%$ (uppercase) level

\subsection{Water Solubility Index}

Based on analysis of variants, the types of stabilizer had a highly significant effect $(\mathrm{P}<0.01)$ on water solubility index of instant garfish condiment. $\mathrm{P}_{1}$ treatment had a highly significant effect from $\mathrm{P}_{2}$ and $\mathrm{P}_{3}$ treatment. $\mathrm{P}_{2}$ treatment had a highly significant effect from $\mathrm{P}_{3}$ treatment. The 
addition of CMC had the higher water solubility index compared to other stabilizer. This was because $\mathrm{CMC}$ had the ability as stabilizer, thickener, increased solubility, and improve texture so that when added to the product, its solubility increased [16]. Correlation of the types of stabilizer on water solubility index can be seen in Figure 4.

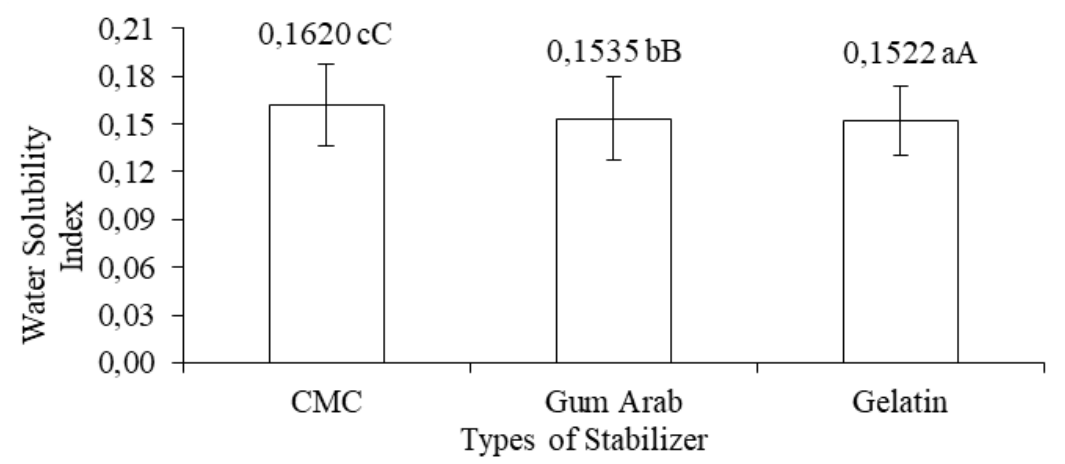

Figure 4. Correlation of the Types of Stabilizer on Water Solubility Index

Note: Different letter notations showed significant effect at $5 \%$ (lowercase) level and highly significant effect at $1 \%$ (uppercase) level

Based on analysis of variants, the percentages of stabilizer had a highly significant effect $(\mathrm{P}<0.01)$ on water solubility index of instant garfish condiment. $\mathrm{P}_{1}$ treatment had a highly significant effect from $\mathrm{P}_{2}, \mathrm{P}_{3}$, and $\mathrm{P}_{4}$ treatment. $\mathrm{P}_{2}$ treatment had a highly significant effect from $\mathrm{P}_{3}$ and $\mathrm{P}_{4}$ treatment. $\mathrm{P}_{3}$ treatment had a highly significant effect from $\mathrm{P}_{4}$ treatment. The higher addition of stabilizer, the more hydroxyl groups that bind to water and increased solubility. The higher solubility, the better quality of the product because it easier to serve [17]. Correlation of the percentages of stabilizer on water solubility index can be seen in Figure 5.

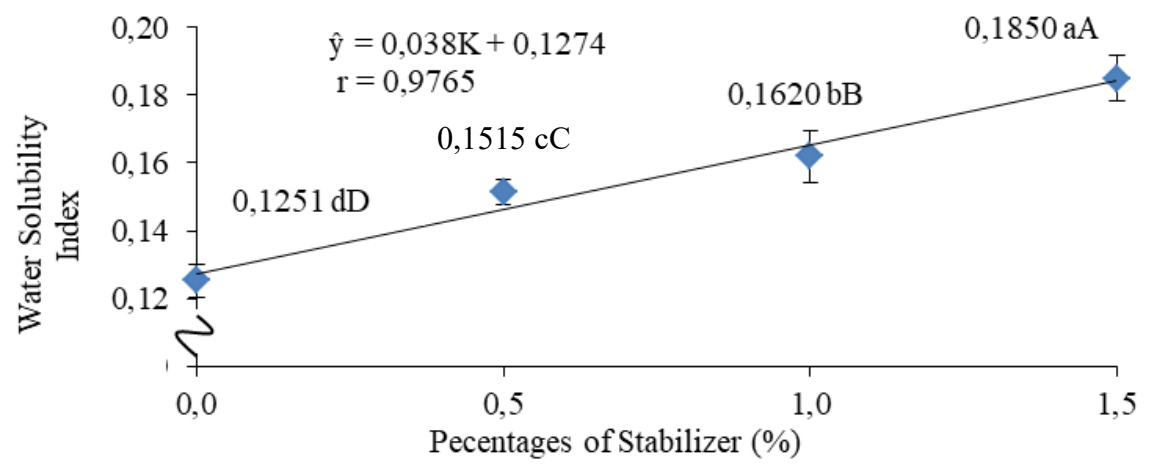

Figure 5. Correlation of the Percentages of Stabilizer on Water Solubility Index

\subsection{Vitamin $\mathrm{C}$}

Based on analysis of variants, the types of stabilizer had a highly significant effect $(\mathrm{P}<0.01)$ on vitamin $\mathrm{C}$ of instant garfish condiment. $\mathrm{P}_{1}$ treatment had a highly significant effect from $\mathrm{P}_{2}$ and $\mathrm{P}_{3}$ treatment. $\mathrm{P}_{2}$ treatment had a highly significant effect from $\mathrm{P}_{3}$ treatment. The addition of CMC had the higher vitamin C compared to other stabilizer. CMC can formed a film layer and 
had a strong binding power, so that the nutritional components of the product was more protected [18]. Correlation of the types of stabilizer on vitamin C can be seen in Figure 6.

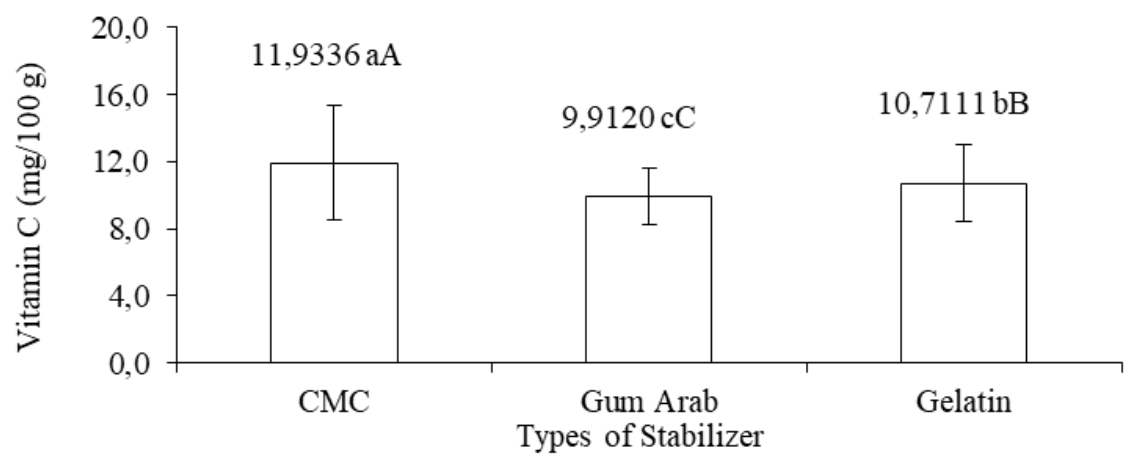

Figure 6. Correlation of the Types of Stabilizer on Vitamin C

Note: Different letter notations showed significant effect at 5\% (lowercase) level and highly significant effect at $1 \%$ (uppercase) level

Based on analysis of variants, the percentages of stabilizer had a highly significant effect $(\mathrm{P}<0.01)$ on vitamin $\mathrm{C}$ of instant garfish condiment. $\mathrm{P}_{1}$ treatment had a highly significant effect from $\mathrm{P}_{2}, \mathrm{P}_{3}$, and $\mathrm{P}_{4}$ treatment. $\mathrm{P}_{2}$ treatment had a highly significant effect from $\mathrm{P}_{3}$ and $\mathrm{P}_{4}$ treatment. $\mathrm{P}_{3}$ treatment had a highly significant effect from $\mathrm{P}_{4}$ treatment. Vitamin $\mathrm{C}$ was a vitamin that easily damaged by high temperature and oxygen. The higher addition of stabilizer increased the colloidal particles attractiveness, so that the space between particles that contained oxygen and vitamin $\mathrm{C}$ damaged due to high temperatures and oxygen can be reduced [19]. Correlation of the percentages of stabilizer on vitamin C can be seen in Figure 7.

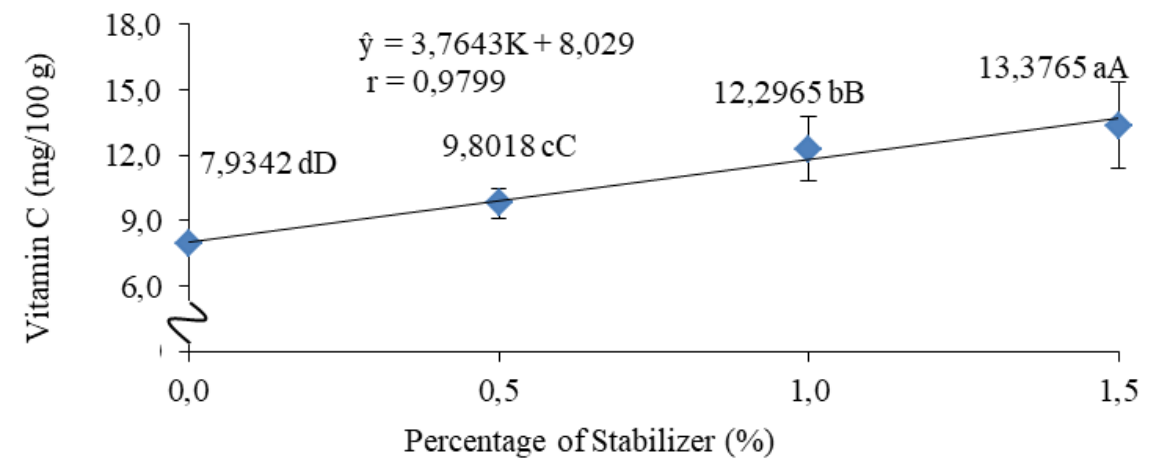

Figure 7. Correlation of the Percentages of Stabilizer on Vitamin C

Note: Different letter notations showed significant effect at $5 \%$ (lowercase) level and highly significant effect at $1 \%$ (uppercase) level

Based on analysis of variants, interaction between the two factors had a highly significant effect $(\mathrm{P}<0.01)$ on vitamin $\mathrm{C}$ of instant garfish condiment. The combination of the types and percentages of stabilizer had a highly significant effect on vitamin $\mathrm{C}$ of instant garfish condiment. The addition of $1.5 \% \mathrm{CMC}$ had the higher vitamin $\mathrm{C}$ compared with other stabilizer. This was because CMC had a strong binding power and can formed film layer and reduced the 
space for free oxygen so that vitamin $\mathrm{C}$ damaged can be reduced. The higher the addition of CMC increased the hydrocolloid particles so that the binding power was stronger [19]. Interaction between the two factors on vitamin $\mathrm{C}$ can be seen in Figure 8.

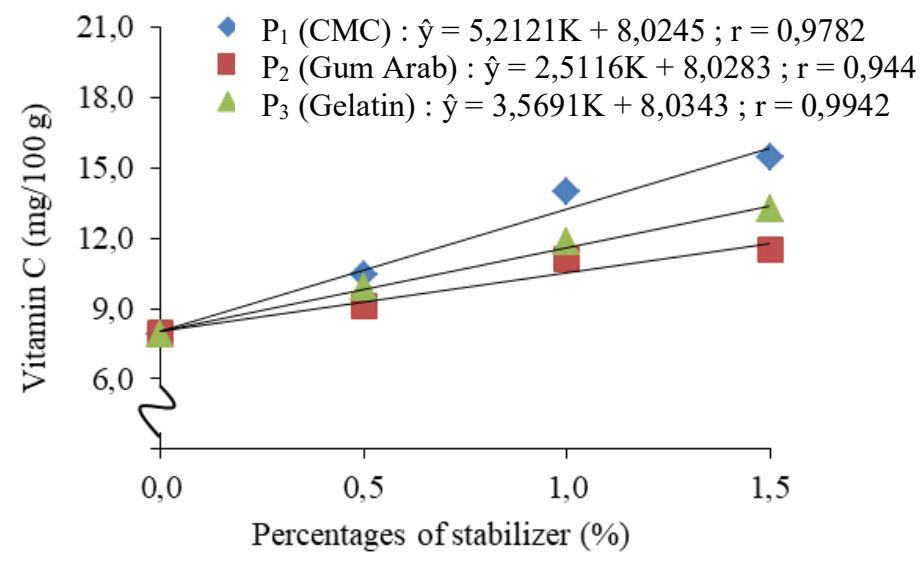

Figure 8. Interaction between the Types and Percentages of Stabilizer with Vitamin C of Instant Garfish Condiment

Note: Different letter notations showed significant effect at 5\% (lowercase) level and highly significant effect at $1 \%$ (uppercase) level

\subsection{Color Index}

Based on analysis of variants, the types of stabilizer had a highly significant effect $(\mathrm{P}<0.01)$ on color index of instant garfish condiment. $\mathrm{P}_{1}$ treatment had a highly significant effect from $\mathrm{P}_{2}$ and $\mathrm{P}_{3}$ treatment. $\mathrm{P}_{2}$ treatment had no significant effect from $\mathrm{P}_{3}$ treatment. The results showed that the color index value was between $18-54{ }^{\circ} \mathrm{Hue}$ that means the color was red due to chili color. In addition, the stabilizer can protected the product from damaged by forming a film layer and binding components on the product [19]. Correlation of the types of stabilizer on color index can be seen in Figure 9.

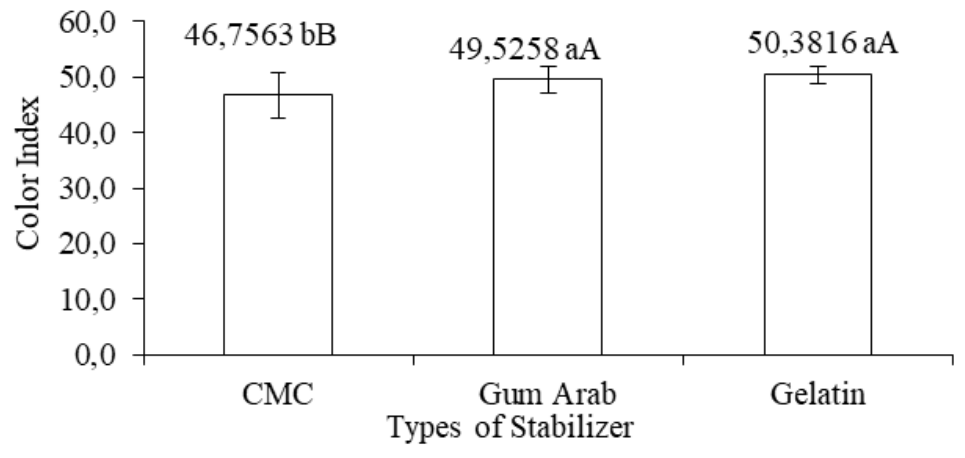

Figure 9. Correlation of The Types of Stabilizer on color index

Note: Different letter notations showed significant effect at 5\% (lowercase) level and highly significant effect at $1 \%$ (uppercase) level 
Based on analysis of variants, the percentages of stabilizer had a highly significant effect $(\mathrm{P}<0.01)$ on color index of instant garfish condiment. $\mathrm{P}_{1}$ treatment had a highly significant effect from $\mathrm{P}_{2}, \mathrm{P}_{3}$, and $\mathrm{P}_{4}$ treatment. $\mathrm{P}_{2}$ treatment had no significant effect from $\mathrm{P}_{3}$ and $\mathrm{P}_{4}$ treatment. $\mathrm{P}_{3}$ treatment had no significant effect from $\mathrm{P}_{4}$ treatment. The higher the percentage of stabilizer, the product was redder that marked by decreasing of color index. This was because the more stabilizer that protected the product [19]. Correlation of the percentages of stabilizer on color index can be seen in Figure 10.

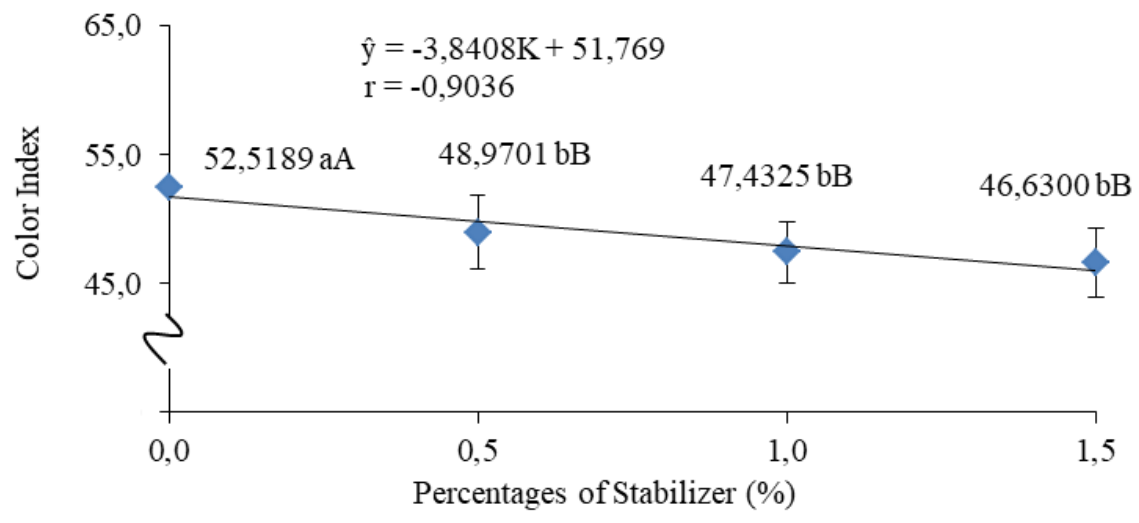

Figure 10. Correlation of the Percentages of Stabilizer on Color Index

Note: Different letter notations showed significant effect at 5\% (lowercase) level and highly significant effect at $1 \%$ (uppercase) level

Based on analysis of variants, interaction between the two factors had a highly significant effect $(\mathrm{P}<0.01)$ on color index of instant garfish condiment. The combination of the types and percentages of stabilizer had significant effect on color index of instant garfish condiment. The addition of $1.5 \% \mathrm{CMC}$ had the lower color index compared with other stabilizer. The results showed that the color index value was between $18-54$ Hue that means the color was red due to chili color. In addition, the stabilizer can protected the product from damaged by forming a film layer and binding components on the product [19]. The higher the percentage of stabilizer, the product was redder that marked by decreasing of color index. Interaction between the two factors on color index can be seen in Figure 11.

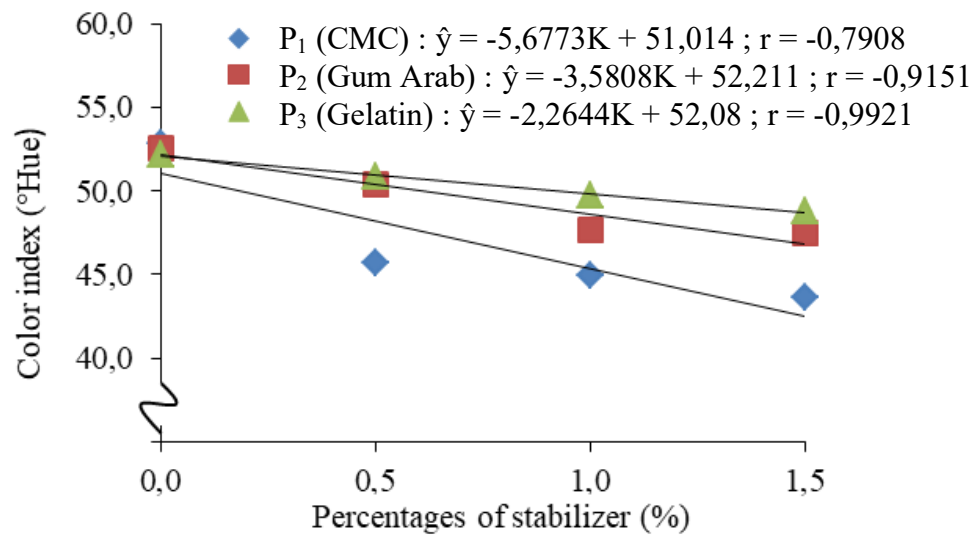


Figure 11. Interaction between the Types and Percentages of Stabilizer with Color Index of Instant Garfish Condiment

Note: Different letter notations showed significant effect at 5\% (lowercase) level and highly significant effect at $1 \%$ (uppercase) level

\subsection{Organoleptic Aroma}

The types of stabilizer had no significant effect $(\mathrm{P}>0.05)$ on organoleptic aroma of instant garfish condiment. In the meantime, based on analysis of variants, the percentages of stabilizer had a highly significant effect $(\mathrm{P}<0.01)$ on organoleptic aroma of instant garfish condiment. $\mathrm{P}_{1}$ treatment had a highly significant effect from $\mathrm{P}_{2}, \mathrm{P}_{3}$, and $\mathrm{P}_{4}$ treatment. $\mathrm{P}_{2}$ treatment had a highly significant effect from $\mathrm{P}_{3}$ and $\mathrm{P}_{4}$ treatment. $\mathrm{P}_{3}$ treatment had a highly significant effect from $\mathrm{P}_{4}$ treatment. The higher the percentages of stabilizer caused decreasing of product damaged. Stabilizer can affected viscosity, texture, form a film layer, and increased binding capacity. The addition of stabilizer can protected the component that contained in the product so damaged can be reduced [19]. Correlation of the percentages of stabilizer on organoleptic aroma can be seen in Figure 12.

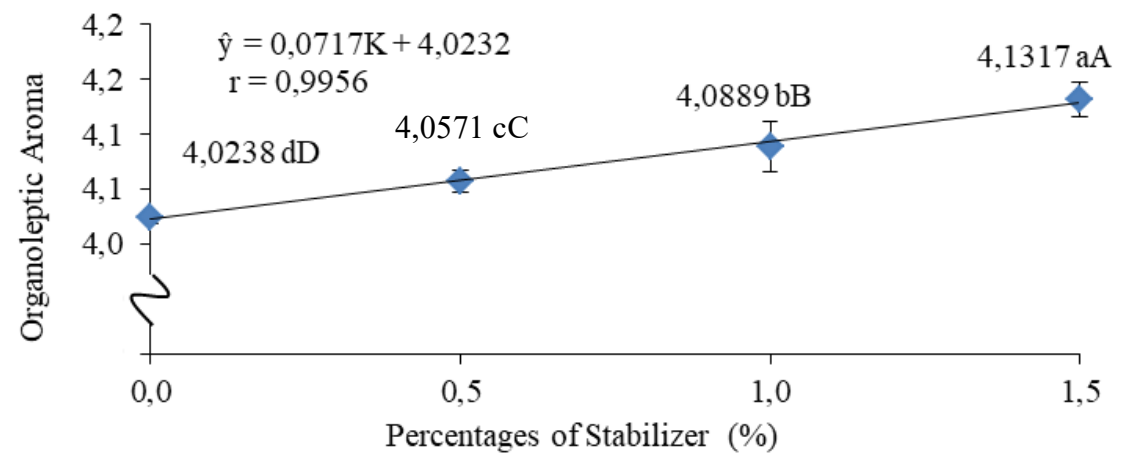

Figure 12. Correlation of the Percentages of Stabilizer on Organoleptic Aroma

Note: Different letter notations showed significant effect at $5 \%$ (lowercase) level and highly significant effect at $1 \%$ (uppercase) level

\subsection{Organoleptic Taste}

The types and percentages of stabilizer and interaction between the two factors had no significant effect $(\mathrm{P}>0.05)$ on organoleptic taste of instant garfish condiment.

\section{Conclusions}

The types and percentages of stabilizer have an effect on the quality of instant garfish condiment. The more percentages of stabilizers added, increased the value of water solubility index, vitamin $\mathrm{C}$, organoleptic aroma, and taste. While the value of water absorption index and color index decreased. Based on research that has been done, the best treatment product was resulted from the use of $1.5 \% \mathrm{CMC}$ as stabilizer because it can provide the most optimal quality of instant garfish condiment. 


\section{Acknowledgments}

This research was supported by Department of Food Science and Technology, Faculty of Agriculture, Universitas Sumatera Utara who provided insight and expertise that greatly assisted the research.

\section{REFERENCES}

[1] V. Dotulong, C. N. Patty, and I. K. Suwetja, "Mutu ikan roa (Hemirhampus sp) asap yang dijual di pasar bersehati kota manado sulawesi utara," [The quality of smoked garfish (Hemirhampus sp) sold in bersehati market manado city north Sulawesi,] Jurnal Media Teknologi Hasil Perikanan, vol. 6, no. 3, pp. 281-286, 2018.

[2] G. R. B. Kusumah, "Pengaruh formula dan perbandingan bumbu serbuk dengan santan serbuk terhadap karakteristik bumbu gulai serbuk dengan metode foam-mat drying," [Effect of formula and comparison of seasoning powder with coconut milk powder on the characteristics of curry seasoning powder with foam-mat drying method,] Thesis, University of Pasundan, Bandung, 2017.

[3] J. W. Supit, T. M. Langi, and M. M. Ludong, "Analisis sifat fisikokimia dan organoleptik sambal cahero," [Analysis of physicochemical and organoleptic properties of cahero condiment,] Jurnal Ilmu Pertanian BPTP Yogyakarta, vol. 17, no. 1, pp. 90-103, 2014.

[4] D. Agnesty, T. K. Karo, and I. Suhaidi, "Pengaruh perbandingan andaliman dengan batang kecombrang dan suhu pengeringan terhadap mutu bubuk sambal andaliman," [Effect of ratio of sichuan pepper with torch ginger stem and drying temperature on the quality of sichuan pepper condiment powder,] Jurnal Rekayasa Pangan dan Pertanian, vol. 5, no. 3, pp. 454-461, 2017.

[5] D. Irtadha, "Pengaruh penambahan asam sunti dan perbandingan gum arab dengan gelatin terhadap mutu bumbu bubuk gulai aceh," [The effect of the addition of asam sunti and ratio of arabic gum and gelatine on the quality of aceh's curry powder,] Thesis, University of Sumatera Utara, Medan, 2017.

[6] S. Sumarni, M. Z. Muzakkar, and Tamrin, "Pengaruh penambahan cmc (carboxy methyl cellulose) terhadap karakteristik organoleptik, nilai gizi, dan sifat fisik susu ketapang (Terminallia catappa L.,)" [Effect of addition concentration cmc (carboxy methyl cellulose) to organoleptic characteristics, physical, and nutritional values of ketapang milk (Terminallia catappa L.),] J. Sains dan Teknologi Pangan, vol. 2, no. 3, pp. 604-614, 2017.

[7] E. P. Ketaren, S. Ginting, and E. Julianti, "Pengaruh perbandingan gum arab dengan pektin sebagai penstabil terhadap mutu selai wortel nenas," [The effect of ratio gum arabic and pectin as a stabilizer on the quality of carrot pineapple jam,] Jurnal Rekayasa Pangan dan Pertanian, vol. 5, no. 1, pp. 136-139, 2017.

[8] M. Pertiwi, Y. Atma, A. Z. Mustopa, and R. Maisarah, "Karakteristik fisik dan kimia gelatin dari tulang ikan patin dengan pre-treatment asam sitrat," [Physical and chemical characteristics of gelatin from pangasius catfish-bone with pre-treatment of citric acid,] Jurnal Aplikasi Teknologi Pangan, vol. 7, no. 2, pp. 83-91, 2018.

[9] I. D. Katsavou, K. C. T. Tsikopoulos, P. N. Eleni, and M. K. Krokida, "Sensorial, functional, optical, and thermal properties of inulin enriched expanded products," International Food Research Journal, vol. 26, no. 2, pp. 657-670, 2019.

[10] S. A. Padang and R. M. Maliku, "Penetapan kadar vitamin c pada buah jambu biji merah (Psidium guajava L.) dengan metode titrasi Na-2,6 dichlorophenol indophenol (DCIP)," [Determination of vitamin $\mathrm{c}$ in red guava fruit (Psidium guajava L.) with the Na-2,6 dichlorophenol indophenol (DCIP) titration method] Media Farmasi, vol. 13, no. 2, pp. 16, 2017. 
[11] A. S. Sinaga, "Segmentasi ruang warna $\mathrm{L}^{*} \mathrm{a} * \mathrm{~b}$," [The segmentation of the color space L*a*b,] Jurnal Mantik Penusa, vol. 3, no. 1, 2019.

[12] I. P. Tarwendah, "Jurnal review: studi komparasi atribut sensoris dan kesadaran merek produk pangan," [Comparative study of sensory attributes and brand awareness in food product: a review] Jurnal Pangan dan Agroindustri, vol. 5, no. 2, pp. 66-73, 2017.

[13] E. Tantono, R. Effendi, and F. H. Hamzah, "Variasi rasio bahan penstabil cmc (carboxy methyl cellulose) dan gum arab terhadap mutu velva alpukat (Parsea americana Mill.)" [Variations ratio of stabilizer $\mathrm{cmc}$ and arabic gum on the quality of avocado velva (Parsea americana Mill.,)] JOM Faperta, vol. 4, no. 2, pp. 1-15, 2017.

[14] N. Phisut, "Spray drying technique of fruit juice powder: some factors influencing the properties of product," Int. Food Res. J, vol. 19, no. 4, pp. 1297-1306, 2012.

[15] M. Widyaningtyas and W. H. Susanto. "Pengaruh jenis dan konsentrasi hidrokoloid (carboxy methyl cellulose, xanthan gum, dan karagenan) terhadap karakteristik mie kering berbasis pasta ubi jalar varietas ase kuning," [Effect of type and concentration of hydrocolloids (carboxy methyl cellulose, xanthan gum, and carrageenan) on characteristic dried noodle based sweet potato variety yellow ase paste,] Jurnal Pangan dan Agroindustri, vol. 3, no. 2, pp. 417-423. 2014.

[16] D. Silsia, Z. Efendi, and F. Timotius, "Karakterisasi karboksimetil selulosa (cmc) dari pelepah kelapa sawit," [Characterization of carboxymethyl cellulose $(\mathrm{cmc})$ of palm midrib,] Jurnal Agroindustri, vol. 8, no. 1, pp. 53-61, 2018.

[17] H. Herawati, "Potensi hidrokoloid sebagai bahan tambahan pada produkpangan dan nonpangan bermutu," [The hydrocolloids potential as additive materials to the qualifiedfood and non-food products,] Jurnal Litbang Pertanian, vol. 37, no. 1, pp. 17-25, 2018.

[18] S. Hidayati, Zulferiyenni, and W. Satyajaya, "Optimasi pembuatan biodegradable film dari selulosa limbah padat rumput laut Eucheuma cottonii dengan penambahan gliserol, kitosan, $\mathrm{cmc}$, dan tapioka, [Optimization of making biodegradable films from cellulose solid waste seaweed Eucheuma cottonii with the addition of glycerol, chitosan, cmc, and tapioca,] JPHPI, vol. 22, no. 2, pp. 340-354, 2019.

[19] I. N. Farikha, C. Anam, and E. Widowati, "Pengaruh jenis dan konsentrasi bahan penstabil alami terhadap karakteristik fisikokimia sari buah naga merah (Hylocereus polyrhizus) selama penyimpanan," Jurnal Teknosains Pangan, vol. 2, no. 1, pp. 30-38, 2013. 